\title{
Design Guidelines for B2C E-Commerce in Virtual Worlds
}

\author{
Minh Quang Tran \\ Department of Computing \\ The Open University, UK \\ Milton Keynes, MK7 6AA \\ m.tran@open.ac.uk
}

\author{
Shailey Minocha \\ Department of Computing \\ The Open University, UK \\ Milton Keynes, MK7 6AA \\ s.minocha@open.ac.uk
}

\author{
Dave Roberts \\ Department of Computing \\ The Open University, UK \\ Milton Keynes, MK7 6AA \\ d.roberts@open.ac.uk
}

\author{
Angus Laing \\ School of Business and Economics \\ Loughborough University, UK \\ Leicestershire, LE11 3TU \\ a.w.laing@lboro.ac.uk
}

\author{
Darren Langdridge \\ Department of Psychology \\ The Open University, UK \\ Milton Keynes, MK7 6AA \\ d.langdridge@open.ac.uk
}

\begin{abstract}
Virtual worlds are three-dimensional (3D) persistent multi-user online environments in which users interact through avatars. Virtual worlds support many kinds of activities, including education, socialising, gaming and e-commerce. Our research focuses on how virtual worlds can be used to facilitate business-to-consumer (B2C) e-commerce involving real items. Examples of affordances of virtual worlds for e-commerce include 3D simulations, multi-user environments and avatarbased interactions. We have conducted empirical research to gather data about consumers' experiences in virtual worlds to understand ways to utilise their affordances for B2C e-commerce. Based on our empirical research and a literature review, we have derived design guidelines for the design and evaluation of $\mathrm{B} 2 \mathrm{C}$ e-commerce environments involving virtual worlds. This poster presents a summary of the research project and a subset of the guidelines.
\end{abstract}

Consumer experience, design guidelines, e-commerce, design heuristics, interaction design, service design, service encounter, user experience design, virtual worlds

\section{BACKGROUND}

Virtual worlds are three-dimensional (3D) persistent multi-user online environments in which users interact through avatars. Virtual worlds can support many kinds of activities, including education, socialising, gaming and e-commerce. Our research focuses on how virtual worlds can be utilised to facilitate business-to-consumer (B2C) e-commerce involving virtual and real products and services.

Virtual worlds have several affordances that can potentially be utilised to enhance the B2C ecommerce experience, such as 3D simulations of products, multi-user and avatar-based real-time interactions (Kaplan and Haenlein, 2009; Hemp, 2006). Businesses can provide 3D simulations of products to allow consumers to learn about products in a way that is more engaging than $2 \mathrm{D}$ images. Interactions in a 3D environment can facilitate feelings of presence in the retail environment, which results in a more engaging experience. Businesses can also use avatars to interact with consumers in real-time to enhance trust. Yet despite the potential, there are only a few real world businesses using virtual worlds effectively for B2C e-commerce.

\section{OUR RESEARCH}

We are conducting empirical research with consumers and designers who have experience in virtual worlds. In the last one and a half years, we have carried out three qualitative studies. The first study was to understand consumers' experiences of the consumption process in virtual worlds. The second study investigated the affordances of virtual worlds for e-commerce. The third study was to understand consumers' perceptions of virtual world's affordances for e-commerce. We are now conducting another study with designers to elicit design guidelines that they currently use to design e-commerce environments in virtual worlds.

The results from our empirical research have been synthesised to derive a set of design guidelines for $\mathrm{B} 2 \mathrm{C}$ e-commerce in virtual worlds. The design guidelines are targeted for designers and usability practitioners who are designing or evaluating ecommerce environments in virtual worlds. 


\section{GUIDELINES FOR B2C E-COMMERCE IN VIRTUAL WORLDS}

Our design guidelines are derived mainly from our empirical research. However, they are informed and supported by the academic literature, books on usability and tutorials for designing virtual world environments (e.g. http://www.nci-sl.info/blog/ and http://wiki.secondlife.com/wiki/Video Tutorials).

We organised the guidelines using the service encounter model. The service encounter model divides the consumption process into three stages: the pre-purchase, the purchase and the postpurchase stage (Bitner and Booms, 1990). Our guidelines are also divided into these three stages.

Different design goals are emphasised in different stages of the service encounter. The emphasis in the pre-purchase stage is on attracting consumers' attention and setting the consumers' expectations. The emphasis in the purchase stage is on facilitating the $\mathrm{B} 2 \mathrm{C}$ interactions and meeting the expectations of consumers which were set in the pre-purchase stage. In the post-purchase stage, the emphasis is on resolving consumers' queries and resolving any remaining expectations.

Table 1. Guidelines for B2C e-commerce in virtual worlds

\begin{tabular}{|c|c|c|}
\hline $\begin{array}{l}\text { Pre-Purchase } \\
\text { Stage Guidelines }\end{array}$ & Example & $\begin{array}{c}\text { Support from } \\
\text { literature }\end{array}$ \\
\hline $\begin{array}{l}\text { Facilitate product } \\
\text { discovery and } \\
\text { exploration with } \\
\text { consumers }\end{array}$ & $\begin{array}{l}\text { Organise events } \\
\text { for socialising or } \\
\text { gaming where } \\
\text { products are } \\
\text { visible }\end{array}$ & $\begin{array}{l}\text { Innovativeness } \\
\text { (Zeithhaml et } \\
\text { al., 2002) }\end{array}$ \\
\hline $\begin{array}{l}\text { Clearly identify } \\
\text { real world status } \\
\text { of the business }\end{array}$ & $\begin{array}{l}\text { Use branding } \\
\text { and signage that } \\
\text { is consistent } \\
\text { with the real } \\
\text { world business }\end{array}$ & $\begin{array}{l}\text { Enhance trust } \\
\text { (Petre et al., } \\
\text { 2006) }\end{array}$ \\
\hline $\begin{array}{l}\text { Make products } \\
\text { searchable }\end{array}$ & $\begin{array}{l}\text { List products on } \\
\text { in-world and } \\
\text { website search } \\
\text { engines }\end{array}$ & $\begin{array}{l}\text { Search } \\
\text { effectiveness } \\
\text { (Petre et al., } \\
\text { 2006) }\end{array}$ \\
\hline $\begin{array}{l}\text { Purchase Stage } \\
\text { Guidelines }\end{array}$ & Example & $\begin{array}{l}\text { Support from } \\
\text { literature }\end{array}$ \\
\hline $\begin{array}{l}\text { Make in-store } \\
\text { navigation intuitive }\end{array}$ & $\begin{array}{l}\text { Clearly mark } \\
\text { and map out the } \\
\text { store layout }\end{array}$ & $\begin{array}{l}\text { Navigation } \\
\text { support } \\
\text { (Sutcliffe and } \\
\text { Gault, 2004) }\end{array}$ \\
\hline $\begin{array}{l}\text { Design for } \\
\text { changing camera } \\
\text { angles }\end{array}$ & $\begin{array}{l}\text { Do not add walls } \\
\text { or ceilings that } \\
\text { may obstruct } \\
\text { view of products }\end{array}$ & $\begin{array}{l}\text { Unoccluded } \\
\text { camera views } \\
\text { (Shneiderman, } \\
\text { 2003) }\end{array}$ \\
\hline $\begin{array}{l}\text { Make information } \\
\text { about products } \\
\text { readily available } \\
\text { and abundant }\end{array}$ & $\begin{array}{l}\text { Embed textual } \\
\text { information } \\
\text { about products } \\
\text { in objects }\end{array}$ & $\begin{array}{l}\text { Help and } \\
\text { documentation } \\
\text { (Nielsen, } \\
\text { 2005) }\end{array}$ \\
\hline $\begin{array}{l}\text { Facilitate the } \\
\text { feeling of social } \\
\text { presence }\end{array}$ & $\begin{array}{l}\text { Interact using } \\
\text { avatars that } \\
\text { resemble people }\end{array}$ & $\begin{array}{l}\text { Natural } \\
\text { engagement } \\
\text { (Sutcliffe and } \\
\text { Gault, 2004) }\end{array}$ \\
\hline
\end{tabular}

\begin{tabular}{|l|l|l|}
\hline $\begin{array}{l}\text { Provide high- } \\
\text { fidelity product } \\
\text { simulations }\end{array}$ & $\begin{array}{l}\text { Model products } \\
\text { in 3D }\end{array}$ & $\begin{array}{l}\text { Virtual } \\
\text { experience (Li } \\
\text { et al., 2001) }\end{array}$ \\
\hline $\begin{array}{l}\text { Post-Purchase } \\
\text { Stage Guidelines }\end{array}$ & Example & $\begin{array}{l}\text { Support from } \\
\text { literature }\end{array}$ \\
\hline $\begin{array}{l}\text { Support } \\
\text { appropriation and } \\
\text { customisation of } \\
\text { products }\end{array}$ & $\begin{array}{l}\text { Provide } \\
\text { instructions on } \\
\text { customisation }\end{array}$ & $\begin{array}{l}\text { Responsivene } \\
\text { ss (Zeithaml et } \\
\text { al, 2002) }\end{array}$ \\
\hline $\begin{array}{l}\text { Facilitate re- } \\
\text { contact between } \\
\text { consumer and } \\
\text { business }\end{array}$ & $\begin{array}{l}\text { Embed } \\
\text { company } \\
\text { information in } \\
\text { products }\end{array}$ & $\begin{array}{l}\text { Contact } \\
\text { methods } \\
\text { (Zeithaml, } \\
\text { Encourage }\end{array}$ \\
$\begin{array}{l}\text { Siscussion about } \\
\text { products }\end{array}$ & $\begin{array}{l}\text { Support social } \\
\text { networks and } \\
\text { dialogue } \\
\text { between } \\
\text { consumers }\end{array}$ & $\begin{array}{l}\text { Brand } \\
\text { community } \\
\text { (McAlexander, } \\
\text { et al., 2002) }\end{array}$ \\
\hline \multicolumn{2}{|l}{} \\
\hline
\end{tabular}

\section{REFERENCES}

Li, H., Daugherty, T., \& Biocca, F. (2001). Characteristics of Virtual Experience in Electronic Commerce: A Protocol Analysis. Journal of Interactive, 15(3), 13-30.

Bitner, M. J., Booms, B. H., \& Tetreault, M. S. (1990). The Service Encounter: Diagnosing Favorable and Unfavorable Incidents. Journal of Marketing, 54(1), 71-84.

Hemp, P. (2006). Are You Ready for E-tailing 2.0? Harvard Business Review June 2006, 28.

Kaplan, A. M., \& Haenlein, M. (2009). The Fairyland of Second Life: Virtual Social Worlds and How to Use Them. Business Horizons, 52(6), 563572.

McAlexander, J. H., Schouten, J. W., \& Koenig, H. F. (2002). Building Brand Community. The Journal of Marketing, 66(1), 38-54.

Nielsen, J. (2005). 10 Heuristics for User Interface Design. Retrieved Feb 16, 2011 from http://www.useit.com/papers/heuristic/heuristic_list. $\mathrm{html}$

Petre, M., Minocha, S., \& Roberts, D. (2006). Usability Beyond the Website: An EmpiricallyGrounded E-Commerce Evaluation Instrument for the Total Customer Experience. Behaviour and Information Technology, 25(2), 189-203.

Shneiderman, B. (2003). Why Not Make Interfaces Better than 3D Reality? IEEE Computer Graphics and Applications, 23(6), 12-15.

Sutcliffe, A. (2004). Heuristic Evaluation of Virtual Reality Applications. Interacting with Computers, 16(4), 831-849.

Zeithaml, V. A, Parasuraman, A, \& Malhotra, A. (2002). Service Quality Delivery through Web Sites: A Critical Review of Extant Knowledge. Journal of the Academy of Marketing Science, 30(4), 362-375. 